\title{
Turkish Foreign Policy to European Union and Its Chance to be a European Union Member
}

\author{
Anton Minardi \\ Pasundan University Bandung, West Java 40261, Indonesia \\ antonminardi@gmail.com \\ Submitted: 03 June 2016, Accepted: 17 October 2016
}

\begin{abstract}
Abstrak
Peradaban Turki modern dibentuk atas sekularitas negara dengan karakteristik khusus yang diadopsi dari kerajaan Islam Ottoman. Wilayah strategis Turki yang membentang dari benua Asia hingga Eropa telah membentuk politik luar negeri Turki selama berabad-abad dimana negara ini menempatkan diri sebagai jembatan yang menghubungkan kedua benua dengan motto "peace at home, peace abroad. Meskipun demikian Politik luar negeri Turki dianggap lebih condong pada Eropa karena kesamaan identitas yang dimilikinya. Hal ini ditandai dengan keikutsertaan Turki dalam beberapa agenda internasional Uni Eropa seperti Europe Council tahun 1949, North Atlantic treaty Organization (NATO) 1952, European Economic Community (EEC) 1959, maupun agenda-agenda lainnya dan secara resmi mendaftar sebagai anggota Uni Eropa pada 14 April 1987. Akan tetapi, kebijakan Turki terhadap krisis Cyprus dan Etnis Kurdi menyebabkan kecanggungan bagi negara-negara yang tergabung dalam Uni Eropa. Tulisan ini menjelaskan politik luar negeri Pemerintah Turki terkait isu keanggotaan dalam UE serta pengaruh Amerika dalam kasus tersebut.

Kata kunci: Geopolitik Turki, Politik Luar Negeri Turki, Uni Eropa, Peran Amerika, Isu keanggotaan Turki,
\end{abstract}

\begin{abstract}
The Modern Turkish was established as a secular state whose special characteristic was brought from the Ottoman Islamic empire. The area of Turkey's geopolitics is stretching from Asian to European continent, and always more inclined to the West. These circumstances have formed Turkish foreign policy for decades by indicating the bridging for the Asia on the East and Europe on the West with its motto "peace at home, peace abroad". As the secular state, Turkey recognized themselves as a country whose identity similar to the Western states given the fact that Turkish foreign policy always strive to join the European Union as their priority, as well as Turkey as a NATO member. Turkey showed a great effort through their involvement in various European affairs such as member of the Europe Council 1949, North Atlantic Treaty Organization (NATO) 1952, European Economic Community (EEC) 1959, member of the Organisation for Economic Co-operation and Development (OECD) 1961, European Community 1964, the Organization for Security and Co-operation in Europe (OSCE) in 1973, and officially applied to be member of European Union (EU) on April 141987. However, some obstacles remain such as the reluctance of the West toward Turkish performance in dealing with the Cyprus and Kurdish crises. This article explains how Turkish government perform its foreign policy by considering the discussion of Turkish Geopolitics, Turkish Foreign Policy, Turkey - EU Relation, Membership Issue in the EU, The Role of the U.S. to Turkish Membership in the EU, and the Chances for Turkey to be the EU member. Keywords: Turkish Geopolitics, Turkish Foreign Policy, European Union, the Role of the U.S., Membership Issues.
\end{abstract}

\section{INTRODUCTION}

For a long-time, Turkey is well known as part of European country due to the geographic location of the continent and culture, especially from postOttoman Caliphate culture. It is also an alliance to the West and has become the member of NATO, an organisation of the West European security alliance. It is necessary for Turkey to be the member of the European Union (EU) referring to its relations and proximity to the EU states. It was unsurprising reason that Turkey is viewed to prioritise of its membership in the EU.

Before discussing Turkish foreign policy toward the European Union, it is better to know the definition of foreign policy, how it is developed and how to implement it. The old definition of foreign policy is understood as a formulation of national interests and 
put it into international fora as advance goals, to gain the goals, and act to be a winner in the international game. In the new form of foreign policy, it remained as a more complex affair.

Laura Neack explored foreign policy in broad view. She explained that "Foreign policy is made and conducted in complex domestic and international environments as the results from the work of coalitions of interested domestic and international actors and groups. The issues are often linked and delinked, reflecting the strength of various parties and their particular concerns. It derives from issues of domestic politics as well as foreign relations, and it needs to be multilevel and multifaceted in order to confront the complicated sources and nature of foreign policy." (Neack, 2008).

Charles Hermann defines foreign policy as "the discrete purposeful action that results from the political level decision of an individual or group of individual. (It is) the observable artifact of a political level decision. It is not the decision, but a product of the decision." His definition more close to the meaning of foreign policy as the behaviour of states (Neack, 2008).

On the opposite, Bruce Russet, Harvey Starr, and David Kinsella in broader definition of foreign policy asserted: "We can think of a policy as a program that serves as a guide to behaviour intended to realize the goals of an organization has set for itself.... foreign policy is thus a guide to actions taken beyond the boundaries of the state to further the goals of the states." They defined that if study foreign policy its must involve "formulations and implementation" of policy (Neack, 2008).

Furthermore, Deborah Gerner embraced the interest of Hermann in states behaviour and the focus of Russet, Starr, and Kinsella's on programs or guides. She defined foreign policy as "the intentions, statements, and actions of an actor - often, but not always, a state - directed toward the external world and the response of other actors to these intentions, statements and actions." (Neack, 2008).

Robert J. Jackson explained there are three stan- dard models of the foreign policy process. The first is the rational actor model which has six basic steps include distinguish a problem from other; review the values, goals, and objectives in the form of priority; compile the alternative tools to achieve the goals; estimate the costs and benefits would come from each alternative tools; compare the costs and benefits of the other alternatives tools; and selects the maximum advantages with the minimum risks. Second, the organisational process model, it constitutes the standardisation of responses and operations in order to reach their goals. Third, the government or bureaucratic model, it views that various government actors and organisations would produce different goals and its actions, but would happen in a kind of bargain process (Jackson, 2013).

We can conclude that the foreign policy making process could be separated each model in practice, but it might be as an embracement of two or three model as mentioned above. The actors would start from their basic interest towards a standardisation then come to more complex interconnectivity. In the form of interests, interconnectivity foreign policy could be compiled as prioritised and considered as large and long term advantages.

Foreign policy could be implemented globally by diplomacy as the oldest arts of states to pursue their objectives, goals and demands. Diplomacy is used to develop accommodative policies on the specific issues, negotiation in the cases, moderation in solving a problem, and or consider to avoid unsuccessful bargain with deploying a convince, influence, inducement, manipulation, and furthermore coercion by reducing aid, severe diplomatic ties, or punishment in their manner. In public diplomacy, it could employ propaganda, espionage and subversion. The second form of foreign policy implementation is economic strategies in the meaning of positive and negative such as economic cooperation, funds, other aids, sanctions, embargo or boycott. Third, military and coercive strategies, it can include deterrence, corpulence, and arms race (Jackson, 2013). There are also some diplomacy techniques such as conferences, meetings, visits, 
alliances, containment, détente, until army deployment and the army coalition's attacks.

In the nature in implementing the foreign policy, it will boost to the use of a diplomacy method rely on the origin and its effectiveness. G.R. Berridge mentioned that diplomacy is an important means to pursue foreign policies whereas in many state actors are still concreted in the ministry of foreign affairs. Diplomacy in the changing nature has very important functions include ceremonial, management, information and communication, international negotiation, the duty of protection and contribution to international order (Berridge, 2010).

Next discussion will focus on the nature of Turkey as the basis of its foreign policy making and implementing. There are some levels in foreign policy implementation as defined into the level of analysis, namely individual level, organisational level, state level and international level. The level analysis would be cover all of the level analysis but obviously show the state and international level of analysis. The research describes how Turkish relations with the European Union, its attempts to be a European Union member, and the latest situation as the response of European Union member for Turkish efforts. It is a descriptive research with qualitative analysis to references.

\section{ANALYSES}

The findings of this paper have revealed some information. Turkish foreign policy has always put an effort to the member to the European Union as its priority. However, the European Union members consider Turkey as a strategic partner as a liberal democracy state but at the same time as a challenge for European "Christian identity" if Turkey became the European Union member. Lastly, some barriers appear as some European populations questioning why Turkey want to be the EU member, how strong Turkey as secular and liberal democracy state due to the dominant Turkish Muslim population, Kurdish crisis and also Cyprus crisis.

\section{TURKISH GEOPOLITICS}

Hudson and Vore mentioned some of the inclusive factors were involved for decision makers consideration in foreign policy including culture, history, geography, economy, political institutions, ideology, demographics, and innumerable other factors in a societal context (Hudson and Vore: 1995).

Figure 1. Republic of Turkey and its Neighbours.

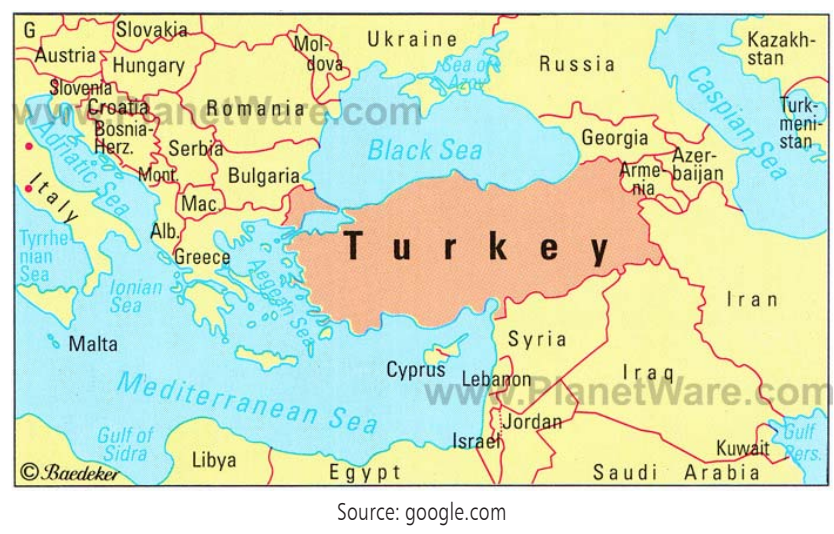

Figure 2. The Ottoman Empire in 1683 and 1914.

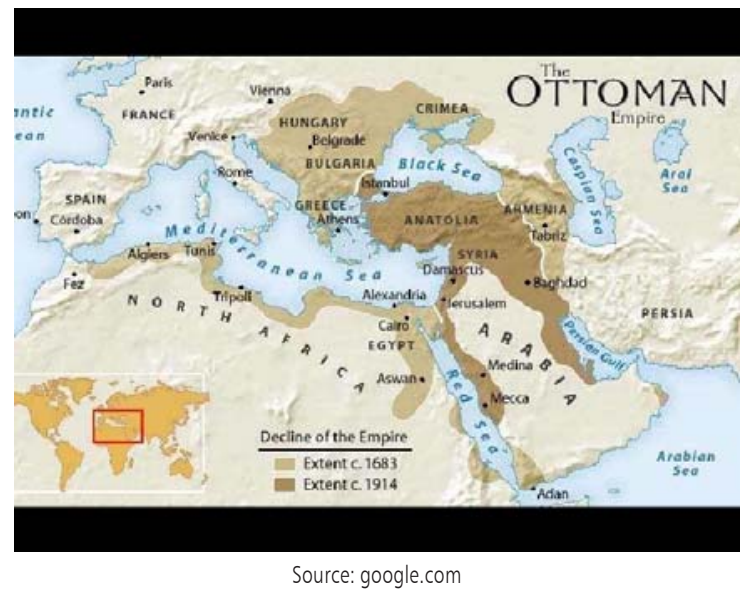

Turkey post-Ottoman is a secular state in a mixture between ASEAN and European cultures based on Islamic views. Historically and geographically Turkey was an Ottoman empire with large geopolitical reign. In that era Ottoman was a dominant world power which encompassed from Anatolia, Mecca and Medina as two Muslim holy cities, Jerusalem as holy city of 3 countries: Jews, Christians and Muslims, Syria and Iraq in the Middle East, Egypt, Libya, Tunis and Algiers in North Africa, also Constantine, Armenia, 
Crimea, Bulgaria, Hungary and Greece as seen in figure 2.

The large geographical reign is also meant large in economic, political and ideological influence and large population movement in demographically. Turkey today has situated on the land of Anatolia, it means this country is powerless compared to Ottoman whose around 85 million citizens and Turkish people diaspora, especially in the former Ottoman areas. Now Turkey lives in the middle of Ottoman former states.

Today the Republic of Turkey is located in Eurasia, on the Anatolian peninsula and East Thrace. Turkey's location on the edge of Western Asia and Southeastern Europe gives it an important position as the gateway between the two continents. Turkey closest enclosures a total of eight countries, some in Europe and others in Asia: Bulgaria, Greece, Georgia, Armenia, Azerbaijan, Iran, Iraq, and Syria. The capital city of Turkey, Ankara which lies in the north-west of Turkey, is the second largest city, after Istanbul. Istanbul, which is located in the west, outspread along the Bosporus, was the capital of Turkey before it became a republic (Maps of World).

Turkey is divided into 81 provinces, each headquartered in its capital, known as the central district. Most provinces are named after their central district. The most populous provinces in Turkey are Istanbul, Ankara, Izmir, Bursa, and Andana (Maps of World).

In geopolitical view, Turkey could play an important role among Asian, European, Eurasia, Middle East and Africa. The state might act a smart role in the various religions, ideologies and cultures among them. From the beginning of the building of the Republic of Turkey, the state follows the western European frame of values with the fulfilment of Turkish cultures.

Turkish actions more close to western European countries that showed attempts to full membership. Cendrowicz reported that the efforts clearly since the membership Europe Council 1949, in North Atlantic Treaty Organization (NATO) on 18 February 1952, member of the Organisation for Economic Cooperation and Development (OECD) in 1961, has been an associate member on 1963, and the Organiza- tion for Security and Co-operation in Europe (OSCE) in 1973, and officially applied to be member of European Union (EU) on April 14, 1987 (Cendrowicz, 2009).

Turkey has also been an associate member of the Western European Union from 1992 to its end in 2011 and is a part of the "Western Europe" branch of the Western European and Others Group (WEOG) at the United Nations. Then Turkey signed a Customs Union agreement with the EU in 1995 and was officially recognised as a candidate for full membership on 12 December 1999, at the Helsinki summit of the European Council. Negotiations were started on 3 October 2005. The membership bid has become a major controversy of the ongoing enlargement of the European Union (Cendrowicz, 2009).

\section{TURKISH FOREIGN POLICY}

In the first Turkish leadership as Attaturk led to found the strong basic of Turkish foreign policy. After the secular revolution, Attaturk led to plan a nice future world in peace. In his secular vision, he brought Turkey into a democratic state and provides a conducive situation. He stated a 'Peace at Home and Peace in the World' as one of the bases of Turkish foreign policy and this has become the important thing to Turkish position in the world (Ministry of Foreign Affairs the Republic of Turkey).

The concept of 'Peace at Home and Peace In the World' implemented in the field of foreign affairs as proofed in the matter of settlement in the form of antagonism towards Western states, and enlarged any possible cooperation with these countries and then strengthen in the future. Another example was in the case of Hatay whereas successfully avoided a gunshot in the integrations the area to the Turkey Nationality, the enhancement of nice Turkish-Greek relations and the close comrade and cooperation spread throughout the Balkans. Also in the case of the Mosul affair, the League of Nations' arbitration was accepted instead of unilateral acts although Mosul was not entered as part of Turkey this clearly portrayed an honour to the international law and peace. Thus, Turkey became the 
only country to be invited to the League of Nations without submitting an application and it joined the organisation in 1932 (the Republic of Turkey, Ministry of Foreign Affairs).

In the further effort to realise the concept of peace, in Ataturk tried to maintain the Turkish foreign policy with tight larger cooperation with several agreements. On 1932 when the Nazi Party hold the ruler power in Germany and Italy made efforts to expand to the Mediterranean and the Balkans, then European states were engaged in an arms race. Ataturk initiated a regional cooperation efforts to prevent the threat to the peace despite the next story was told the World War II. On 9 February 1934, Turkey, Greece, Yugoslavia and Romania signed the Balkan Entente, and on 8 July 1934, Turkey, Iran, Iraq and Afghanistan signed the Sadabad Pact. These are important Turkish efforts actively to maintain a peace and provide security with conducted large cooperation both in the east and the west since years ago when other states passion to war and Turkey keep in a neutral position (The Republic of Turkey, Ministry of Foreign Affairs).

Ilter Turan showed three stages of Turkish foreign policy since the founding of the Republic of Turkey. He told the general stages of Turkish foreign policies including stages of neutrality and low level of involvement (1923 1947), ally loyalty with NATO (1947 1991), and autonomous ally (1992 present). Some internal and external factors resulted from these stages and derived Turkey to latest position (Turan, 2011).

In the first stage, neutrality, from the beginning new Turkish state need to consolidate their regime and build up an economy by avoiding the World War II and extensive international engagements. Strengthen its own sovereignty and cover the Turkish Straits and Mosul-Kirkuk crisis, on the peaceful ways. The Second stage Turkey's leaders would have to drive into a new stage of foreign policy in response toward Soviets expression to coop Turkish Straits and its eastern borders in the end of the World War II by linkage with the Western camp, eventually came into joining NATO in 1952. The next extensive of Turkish foreign affairs shaped by its security and economic dependence on the United States and membership in NATO, and also considerations of Cyprus status. In the period especially in 1980 Turkey more focused to strengthen the value of Lira, Turkish expansion more visible to Russia, Middle East, in forming a "trading state". Furthermore conducted a new tie in trade affairs with the United States and European and Turkish historical relations with the Balkans, the Middle East and North Africa, Iran, the Central Asian republics, China, and Latin America. Then in 1991, post the Cold War and the collapse of the Soviet Union delivered Turkey to the third stage of foreign policy with the unimpeded space for policy making. Turkish attempts were fruitful, today the country became the sixteenth-largest economy in the world and the sixth largest in Europe. The Third Stage, Turkish foreign policy can be divided into two sub-periods 1991-2007 and 2007-present. In the first sub-period (1991 2007) the ruling Justice and Development Party (AKP) derived Turkish foreign policy more prioritised strongly western orientation in more autonomy and as the results of the Turkey candidacy declaration in 1999 and open accession negotiations in 2005. Also expanded its geographical scope such as enforcing a no-fly zone in Northern Iraq, participated in peacekeeping efforts in places like Bosnia, and supported to fight against separatism and terrorism with sending troops to Afghanistan after the terrorist attacks of September 11, 2001. Only a little Turkey's refusal to allow American forces through its territory toward Iraq during the invasion by the U.S. and coalition in 2003. Actually, the government had proposed a plan to U.S. forces through its territory but failed when several key AKP members denied to support it then resulted a little gap between Turkey and U.S until Barack Obama came into White House the relations came into normality. The haunting issue is around the Kurdish separatism where was disturbed Turkish performance in the Middle East (Turan, 2011).

\section{TURKEY-EU RELATION}

The most principal Turkish foreign policy during the new Turkish is the membership in European 
Union (EU). These are some of Turkish explicit efforts to come into EU membership. On September 1959 The European Economic Community (EEC) accepted Turkey's application for associate membership, September 1963 the Ankara Agreement was signed to Custom Union and finally to full EEC membership, December 1968 negotiations on the Additional Protocol started, October 1971 the Additional Protocol was approved in the Turkish Grand National Assembly with 149 votes for and 69 against, September 1986 Turkey-EEC Association Council met, April 1987 Turkey applied for full EEC membership, October 1993 Turkey-EU Association Council met and decided that the technical preparations had been completed and Turkey had fulfilled the greater part of its obligations, March 1995 Turkey-EU Association Council decision on the customs union, December 1999 EU Helsinki Council decision on the candidate status of Turkey, December 2000 The EU Council of Ministers decision on the draft framework regulation on assistance to Turkey in the framework of the preaccession strategy, June 2001 the $40^{\text {th }}$ period meeting of the Turkey-EU Partnership Council was occurred and the $47^{\text {th }}$ meeting of the commission of the TurkeyEU Joint Parliament Committee was occurred in Brussels, December 2001 the European Council was met in Leaken of Belgium. At the end of the summit, it was declared that Turkey had approached to the participation negotiations and Turkey would participate in the convention studies related to the future of the EU, January 2002 the $110^{\text {th }}$ Turkey-EU Association Committee meeting was occurred in Brussels, April 2003 a new European Union Commission was established in the Turkish Parliament in order to negotiate and observe the cohesion of the rules to the EU legislation, April 2004 the referendum was completed in Cyprus the 69,4\% of Turkish people in Cyprus accepted but the $75,85 \%$ of Greek people in Cyprus refused the Annan Plan, June 2005 the heads of governments and states of the EU emphasized on the full application of the decisions referring the decisions of the priority summit and there were no direct statement about Turkey in the final, September
2005 the EU' declaration said that Turkey must recognise Cyprus in the course of its membership talks and give access to its ports and airports to Cypriot ships and planes, January 2006 the Council of the EU adopted a decision on the principles, priorities and conditions contained in the accession partnership with Turkey on 17 January 2006 with No. 15671/05, December 2006 EU member states freeze eight negotiating chapters because Turkey refuses to open its harbours and ports to Greek Cypriot craft, March 2007 the EU and Turkey begin talks on "enterprise and industry policy" the second chapter Ankara has opened (Kapucu \& Palabiyik, 2008).

Müftüler-Baç mentioned that in early 1959 Turkish foreign policy targeted objectives to become a member of the European Community, two years after the Rome Treaty was signed 1957. The earnest has begun 1963 with involvement in an Association Agreement, 1995 signed a Customs Union Agreement. The efforts in 1999 has resulted Turkish position as an official candidate for EU accession and began its accession negotiations in 2005 (Müftüler-Baç, 2015).

Nevertheless some lucid obstacles intercept the Turkish efforts to be an EU member. Hill and Smith pointed some of the most suspension are because Turkey has not completed all the requested demand for normalisation with all EU member states including Cyprus, and allow Cypriot vessels to enter its ports. Moreover there are some opposite argument to Turkish membership came from Austria, France and Germany, as the alternative these states proposed a 'privileged partnership' for Turkey (Hill and Smith, 2011).

Other important factor is the assessment of Turkish unimplemented on Cyprus issue which pulled the EU at the end of 2006 to suspend negotiations for 8 chapters of the Additional Protocol on the Customs Union to Cyprus. Thus, France and Cyprus vetoed the possibility for a vacancy for Turkey to converge in the same point of interest with EU members. These problems led toward the stagnation of Turkish accessible into EU. Other obstacle is that EU members questioned of Turkish commitment in ruling liberal 
democracy as EU norm (Müftüler-Baç, 2015).

Ahmed Dovutoglu stated that Turkey has three methodological and five operational foreign policies. Methodologically formulate as the first principle its "visionary" approach the "crisis-oriented" attitude during Cold War period. Second principle is based on a "consistent and systematic" framework. Third, based on the spread of Turkish soft power. To implement that three methodologies Turkey has five practical principles. First, the balance between security and democracy. It means that it has to provide security without sacrifice freedom and human rights. Second, the zero problems toward neighbours through close cooperation such as with Armenia, Iraq, Syria, Greece and Russia. Then also following in the similar scheme with Bulgaria, Azerbaijan and Ukraine. Moreover Turkey had abolished visa each other with Syria, Tajikistan, Albania, Lebanon, Jordan, Libya and Russia. Third, operate proactive and pre-emptive peace diplomacy, for examples peace regional policy and efforts to make reconciliation between Sunni-Shiite in Iraq, Lebanon-Palestine, Serbia-Bosnia, recover of Darfur and Somalia. Forth, a multi-dimensional foreign policy whereas taking in a complementary position not in competition such as in membership in NATO, relations with Russia, partnership with Eurasia and U.S. and the EU membership proposal. Fifth, Turkey play a "rhythmic diplomacy" evidenced by active and involvement in all international affairs and organizations more over took strategic places such as in U.N. Security Council and South-East European Cooperation Process in soft power and a universal language (Davutoðlu, 2010).

\section{MEMBERSHIP ISSUE IN THE EU}

The membership in EU is the first advance target for Turkish new vision. Ahmet Davutoðlu remarked concerning Turkish "2023 vision" as a necessity. The new Turkish era would set up into strong democracy base on a solid circumstance between society and government bond as the principal capital for worldly activity. Turkey new vision including first, achieve full EU membership and become an influential EU member state in 2023. Second, contending a regional security and economic cooperation. Third, take part as an influential actor in conflict resolution within a region. Fourth, Turkey would be a significant factor in the international organisations arena and become top 10 largest world economies (Davutoðlu, 2010).

Nevertheless, the membership in EU is an old issue but it still as central point for next Turkish foreign policy. We can imagine how big of Turkish efforts for this achievement. Since the first European states were always the first priority for Turkish foreign policy. Turkish involvement in Western community was very large as some notes in the League of Nations 1932, UN 1945, OECD 1948, WTO 1951, NATO 1952, WCO 1952, joined the EEC 1959, EC since 1964, and finally submitted formal application for European Union on April 141987 (Kapucu \& Palabiyik, 2008).

Turkey has requested a set of conditions for its submission process based on the criteria was given through Copenhagen Meeting 2002 include basic standards of democracy, human rights and respect for minorities. In the European Council, 2004 was decided that Turkey had fulfilled the Copenhagen criteria (Kapucu \& Palabiyik, 2008). Then 2005 Turkey must also fulfil 35 criteria as the following preliminary indicative list of chapter headings (Note: This list in no way prejudices the decisions to be taken at an appropriate stage in the negotiations on the order in which the subjects will be dealt with). 1. Free movement of goods; 2. Freedom of movement for workers; 3. Rights of establishment and freedom to provide services; 4 . Free movement of capital; 5. Public procurement; 6. Company law; 7. Intellectual property law; 8. Competition policy; 9. Financial services; 10. Information society and media; 11. Agriculture and rural development; 12. Food safety, veterinary and phytosanitary policy; 13. Fisheries; 14. Transport policy; 15. Energy; 16. Taxation; 17. Economic and monetary policy; 18. Statistics; 19. Social policy and employment (This chapter includes also anti-discrimination and equal opportunities for women and men); 20. Enterprise and industrial policy; 21. Trans-European networks; 22. Regional 
policy and coordination of structural instruments; 23. Judiciary and fundamental rights; 24. Justice, freedom and security; 25. Science and research; 26. Education and culture; 27. Environment; 28. Consumer and health protection; 29. Customs union; 30. External relations; 31. Foreign, security and defence policy; 32. Financial control; 33. Financial and budgetary provisions; 34. Institutions; 35. Other issues (Principles Governing the Negotiations, 2005).

In 2007 European Commission announced Turkish progress to come to a final stage of the membership process. The Commission reported there some improvement in Turkish fulfilment to the EU membership requirements. The improvements include bilateral trade EU-Turkey which reach $\bullet 85$ billion in 2006, public administration, local ownership and participation in municipality management, enhanced the quality of regulations, established one-stop offices service within province and districts and legislative reform of the public administration and civil service system. On the other hand, the Commission also pointed some no progress in the area of more financial transfer to local administrations, transparency and accountability mechanisms and increasing financial resources of local government (Kapucu \& Palabiyik, 2008).

In the field of individual freedom and human rights, Turkey has implemented it in the framework of a secular state. It raises a thought that Turkey has seen more like needs EU but vice versa EU did not need it. Actually, in the world community, every member would need each other, especially in the global era. The membership of Turkey into EU is more public opinion views and political leaders mood rather than economically or administratively. Public opinions might be based on the historical experience or thought that bring into political considerations or moods. Both have close relations in the public affairs in order Turkey-EU.

Cendrowicz mentioned two factors were influenced the Turkey position in EU. Firstly, a Europeans public opinion drop to support Turkey for membership fell down from more than $70 \%$ in 2004 to $42 \% 2008$ and then only $31 \%$ of Europeans support Turkish membership in EU. That opinion proved in June (2009) came into European Parliament elections for the Turkey EU candidacy whereas the members pledging to veto. Second, the political mood might be carried on from the current economic downturn then making the E.U. averse to take on another country struggling under recession (Cendrowicz, 2009).

The Turkey closeness with EU and its admission requirements have influenced to Turkish political norms. Muftuler-Baç asserted although Turkey proves a high level of commitment to EU political norms and criteria until 2008 but it has been disapproved from EU membership objective. One of the most important reasons is that because of Turkey was convinced did not adjust to Cyprus occasions. France and Cyprus had vetoed to continue assessing next chapters of Turkish fulfilment ability to EU criteria. This veto led to pause both EU further enlargement and Turkey's accession into EU membership. In addition EU questions of Turkish commitment to the EU norms of liberal democracy. As the consequence of EU broke down the accession negotiation, and Turkey would rather away from Europe and may would bring the impact of Turkish democratic consolidation (Muftuler-Baç, 2015).

As cite from former European Commissioner Frits Bolkestein said: "Turkey is too big, too poor, and too different." These questioned answered by Modebadze \& Sayin in their article. First, Turkey is too big (Its geographical size approximately $780,580 \mathrm{~km}$ with average populations 80 million in 2016). This current posture of Turkey membership it could strengthen Europe military power significantly. Compare to other European states Turkey is the second largest army. Also, Turkey has plenty young population whom could give benefit to maintain and reinforce for the European security (Modebadze \& Sayin, 2015). It means that Turkey has large potential capital for economic and security because the population mostly well educated.

Second, there were widespread of views that Turkey is too poor and will cost the EU too much base on 
reason of Turkish economic weakness and could be a heavy loading for the European Union. If considering Turkish Gross Domestic Product (GDP) of $\$ 786$ billion, "Turkey has become the 18th most powerful economy in the world." (The World Bank 2014). Therefore, it cannot be presumed as the "sick man of Europe" any more. Turkey has rapid economic growth figure pass the last decades when European states are in economic collapse. The Turkish economic growth in $20109.2 \%$, and $20118.5 \%$ as fastest state in economic growth, this prove that this state could maintain their necessity (Modebadze \& Sayin, 2015).

Third, Turkey is too different. In some European countries spreading knowledge on Turkey sound rather limited and bring to misperceptions and negative understanding. A Sociological research of European citizens described that only around 30\% of European citizens' agreed for welcoming Turkey into the European Union. The other opinions are opposed to Turkish membership into the European Union because of their culture gap among them. Much European doubted that Turkey would follow the identity of Europeans. Their outlook base on the traditional view rather than modernity, that "they lack a Christian identity". There are still in thought that Europe is a club of Christian nations, and the other hand they recognised Turkey as an Islamic country. Referring to the official statistics that Turkish population is dominantly 99\% Muslim, "the majority of whom are Sunni." The Turkish Muslim nature is one of the arguments to oppose for Turkish membership into the European Union. There are also worried Turkish closeness the Middle East conflicts, it might be accommodated religious extremism and fundamentalism in the European Union (Modebadze \& Sayin, 2015).

\section{TURKEY-U.S. RELATION AND ITS SUPPORT FOR TURKISH MEMBERSHIP IN EU}

The relationship between Turkey-U.S. can be seen at several cases in a glance. Since the Ottoman empire, Turkey had a relations with U.S. started with Mutual Recognition 1830 when the first formal relations
James Biddle, David Offley and Charles Rhind were sent as diplomatic envoys to the Ottoman Empire (Turkey) to deal in a treaty of navigation and commerce. Then on September 13, 1831 improved to a term of Diplomatic Relations when the American Legation was established at Constantinople (Istanbul) and sent David Porter as U.S. Charges d'Affaires. In June 18, 1906 the status has elevate to be the Embassy of American and in October 1906 John G. A.

Leishman has accepted credentials as the Ambassador. The diplomatic hampered when February 17, 1917 U.S. declared war toward Germany and furthermore February 17, 1927 the diplomatic relations re-established, with an exchange of notes in Angora, Turkey (Historian).

Turkey-U.S. relations in the post-World period emerged since the Second Cairo Conference in December 1943 and Turkey's joined into the U.S. allies in February 1945, and as a present Turkey was granted as a charter member of the United Nations. The adversity of facing a communist rebellion led by Soviet Union in the Turkish Straits encouraged the United States to proclaim the Truman Doctrine in 1947. The doctrine notified that American want Turkish and Greece security, and followed by large U.S. military and economic support.

It attested in the clandestine operational army, denoted the "Counter-Guerrilla". Futhermore, 1952 Turkey became the North Atlantic Treaty Organization (NATO) after finishing in the Korean War in the name of United Nations forces (Historian).

The Turkey-U.S. relationships run into aloofness when the United States deploy their armies in the Iraq War (to strike down Saddam Hussein) in 2003. In Turkish views, the U.S. strikes would advance for the Kurdistan Workers Party (PKK) in northern Iraq. Furthermore, Turkey worries that the violence in Iraq would give a space for Kurds movement to gain their independence cover Turkey, Iraq, and other Middle Eastern countries territory (Historian).

If we refer to Zanotti there are several reasons of Turkey-U.S. relations. First, The Turkey-U.S. alliance has a long story based on the defense ligament in 
frame of bilateral relations and as NATO member, and also included Turkish involvement in actions in the Balkans, Middle East and Afghanistan after the Cold War. Turkish strategic territory to several global conflicts provide easiness and effectiveness to deploy U.S. and NATO arms, cargo, and personnel valuable to the targets. Turkey also base on the Montreux Convention of 1936 has a controls access to and from the Black Sea. Turkey provided its territory for the U.S. and NATO to deploy their warning missile defence radar and the transformation earlier of a NATO air command unit in Izmir gave Turkey as strategic importance alliance state. The presence of U.S. largest military which generally hosts approximately 1,500 U.S. personnel (and also houses approximately 3,500 Turkish contractors) is in Incirlik (pronounced in-jur-lick) Turkey as the air base near the southern city of Adana. When the Cold War ended, U.S. and NATO have employed Incirlik as the base operations in Iraq, Syria, Bosnia-Herzegovina, Kosovo, and Afghanistan. According to the Bulletin of the Atomic Scientists reported that place as the home of vaults which holding approximately 60-70 U.S tactical, aircraft-deliverable B61 nuclear gravity bombs under NATO auspices in Incirlik. In order to the authority, Turkey holds the right to maintain including to cancel U.S. entrance to Incirlik with three days' edict (Zanotti, 2015). U.S. presence as seen in figure 3.

Second, in 2003 Turkish parliamentary decided not to permit U.S. forces to use their territory especially northern front to confront with Iraq. The decision was impacted to U.S.-Turkey relations crucially and the United States seem to not strongholds as primarily on past legacies of cooperation and span the relations with the Turkish military anymore (Zanotti, 2015).

Third, Turkey still carries on the demand on the advance of U.S. military equipment (include fighter aircraft and helicopters), and Turkish defence industry came into partnership with the United States (such as on the F-35 Joint Strike Fighter). The growth of

Turkish defence industry visible to improve their larger engagement within arms trade transactions or joint military training with non-NATO members, such as China, Russia, Pakistan, and South Korea. This showed that Turkey is attracted to maximise their military technology, diversify its defence relationships, and excessive dependence on the United States. As the result of the target, Turkey has reached increasing of its arms exports and intend to reach at least $\$ 2$ billion in military measures filed in 2016 (Zanotti, 2015).

Figure 3. U.S. and NATO Military Presence in Turkey

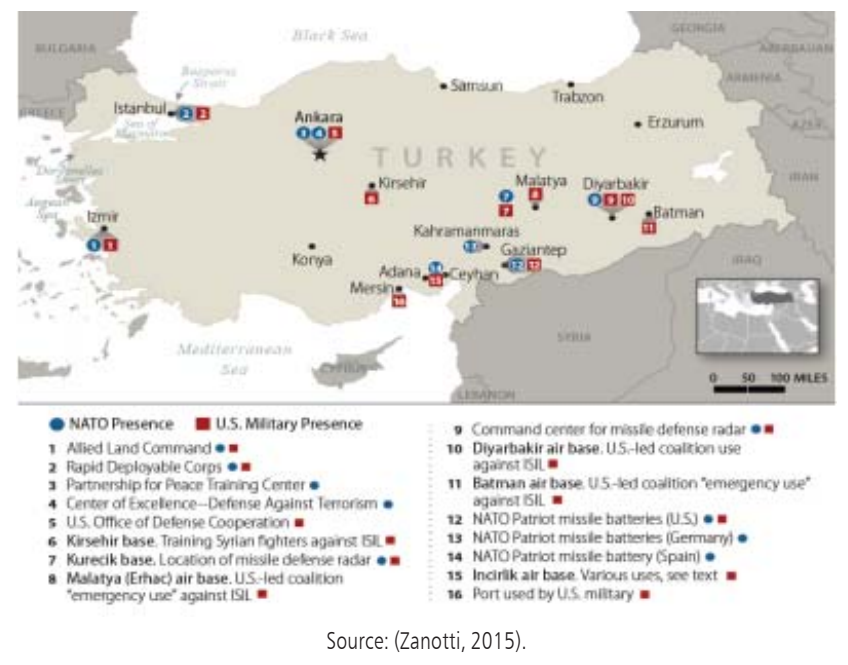

Forth, after joining a customs union with the EU, Turkish involvement has requested in the Transatlantic Trade and Investment Partnership (T-TIP) whereas the United States and the EU doing negotiate to the issue. Latest, considering the complexity negotiations of the T-TIP, and furthermore complicate with other additional trading partners. In addition, Penny Pritzker Secretary of Commerce concluded some specific trade policy "obstacles" for Turkey to involve in T-TIP negotiations during October 2014. On that reason, one expert has advised for Turkey to examine other choices to improve trade options with the United States and or EU rather than involving in TTIP negotiation. In May 2013 the United States and Turkey unanimous to shape a High Level Committee (HLC) (to assess such potential impacts and seek new ways to promote bilateral trade and investment, and 
have held several working-level consultations under the HLC) has offered that Turkey have to attend on the potential matters in T-TIP negotiations to formulate the trade relations among them (Zanotti, 2015).

Fifth, in the end of July 2015, Turkish officials declared that the United States and U.S. coalition would allow to employ Turkish territory including its airspace in order to defeat the Islamic State organisation for anti-IS airstrikes in Syria and Iraq to give straightforward for managing the logistical burdens of coalition operations. The Obama Administration and Turkish officials have agreed to the arrangements as part of a wider plan for U.S.-Turkey coordination to beat out the Islamic State. Previously Turkish government constituted a limitation as the base of action to control flights for Turkey and coalition operations, its consideration give a meaning of maintaining on a "safe zone" in Syria and look forward a support from U.S. to act more aggressive to cast out the Iranian as the back of ruling Syrian regime (Zanotti, 2015).

Since then Turkey-United States relations led to an increasing proximity than the previous time. The current Turkish position in economics development and foreign affairs activity stable the relationship even though they have some differences positions such as in the case of Iraq War 2003, U.S. relationship with Iran and various Kurdish groups could bring the aloofness for bilateral relations.

The Turkey-U.S. close relations gave the benefit for Turkish to gain the U.S. supports in order to Turkish membership in EU. At least U.S. had given attempts to support on the issue. Sarayi mentioned that Washington gave supported for Ankara on the issue of Turkish membership in the EU was became part of the agenda of U.S.-Turkey bilateral relations in the late 1980s. Since the time the agenda became the important pathway for the next Turkey-U.S. relations era. The American officials started to attract for intensive lobbying attempts amidst of U.S. key allies in Europe to open for Turkish membership in EU. Especially, during the 1990s the U.S. was involved in three key developments in EU-Turkey relations (Sayari, 2015).
Sarayi mentioned the U.S. efforts for Turkish membership in EU including on three points. First, in December 1995 Washington clearly involved to in negotiations between Brussels and Ankara eventually has driven to a Customs Union Agreement signature. At the beginning the European Parliament did not passion to take Turkey into Customs Union their mood recognised by many observers then the condition changed by installment until the European Parliament agreed on the agreement. American officials supported and actively approached the members of European Parliament to vote the agreement between the EU and Turkey in the Parliament. Stuart Eisenstadt the chief U.S. Trade Negotiator led the U.S. lobbying attempt in Strasbourg. Obviously, Washington's campaign performed an important role in conditioning to the Turkish inclination (Sayari, 2015).

Second, in December 1999 the U.S. appeared an identic important role in the outcome of the EU Council's Helsinki summit, which formally confessed Turkey's to be EU full membership candidacy. Washington showed clear disagreement to the EU's decision in Luxembourg two years earlier (1997), whereas exempted Turkey from the formal list of EU candidacy for full membership. In 1999, the Clinton administration utilised major pressure through both formal and informal linkages, comprising telephone calls by President Clinton to European leaders, for the turned over decision. Nevertheless new transformations, covering the victory of the Social Democrats went into power in Germany and the end of Greece's opposition for Turkish membership in EU were also very significant factors, but other significant factor also came from high ranking Clinton administration officials rigorous accentuations to their most prominent European counterparts in restoring of the EU's policy on Turkish issue. In the next occasion President Clinton addressed official statement in the EU summit meeting greeted the EU's decision "with pleasure" and emphasized that the U.S. has "long supported Turkey's bid to join the EU in 2003 the United States and Turkey's membership in the Euro- 
pean Union the belief that this would have lasting benefits not only for Turkey, but also for all EU members and the United States." (Sayari, 2015).

Third, foregoing to December 12, 2002 on the EU summit meeting in Copenhagen, 2002, the U.S. once again launched a principal campaign for Turkish advances when come into the EU membership. When President Bush met Tayyip Erdoðan the leader of the Justice and Development Party, in December 11 at the White House, he emphasised Washington's support for Turkey membership in EU and proclaimed that the U.S. "stands side by side with Ankara in its bid to join the European Union.” Bush also holds several phone calls to European leaders while Colin Powell the U.S. Secretary of State boosted his European counterparts to set a date for new Turkish accession for EU membership. Other proof in December 2, U.S. Deputy Secretary of State Paul Wolfowitz for Turkish membership in EU when delivering his speech at the International Institute for Strategic Studies in London, he asserted: "The decision on E.U members is, of course, Europe's to malfc. However, the history suggests that the European Union welcomes to Turkey will be even stronger, and safer and more richly diverse than today. The alternative, exclusionary choice is surely unthinkable." Different with 1995 and 1999, Washington's lobbying campaign in 2002 did not closed to set up on the main objectives of Turkish membership in EU, whereas reach to a specific date for Turkish accession consultations between Ankara and Brussels (Sayari, 2015).

\section{CHANCES TO BE A MEMBER OF THE EUROPEAN UNION}

Referring to the discussion above, we can conclude that if Turkey eager to be an EU member then Turkey has to answer several surrounding questions concerning Cyprus crisis, liberal democracy identity, and Kurdish crisis as the priority among other questions. This was the character of foreign affairs, in the opposite situation each actors have to consider each interests even though could be reached in matters of interests its might "some gain and some loss". As Turkey put on focused that EU as the first foreign policy priority, the efforts would be effective with rises economic cooperation and mutual understanding civilization. The consequences would rise Turkey to rid from Kurdish crisis as last miscomprehension and internally also would ready to admit internal "Islamic clash" and North Cyprus might be loss from its hand.

\section{CONCLUSION}

Turkey always showed its eager to be the European Union member. Internally Turkey has built its states as secular and liberal democracy state as West performance. Turkish state administration also fulfilled the requirement of European Union conditions. Externally Turkish foreign policy set as prioritized to enter the membership of European Union and maintained the close relations with European Union members. There was appeared of U.S. roles as support for Turkish membership in the Union whereas played important matter. Turkey has opened their territory for NATO and U.S. as its showed serious friendship and more close relations with the West. In the case of Cyprus Turkey has fixed relations with Greece and fulfilling non-discrimination condition in Cyprus Island.

Long term of Turkish's efforts gained the development in its attempts to be the European Union member but its unsuccessful story like Bulgaria or Croatia which more easy to gain their membership in EU. It seems that Turkey must show more earnest to act to enter the Union internally and externally and answer the questions concerning Cyprus and Kurdish crisis and as democratic state.

\section{REFERENCES}

\section{BOOKS}

Berridge, G.R.. 2010. Diplomacy-Theory and Practice. New York: Palgrave.

Cendrowicz, Leo. 2009. Fifty Years On, Turkey Still Pines to Become European. (Online), (http://content.time.com/time/world/article/ 0,8599,1920882,00.html).

Davutoglu, Ahmet. 2010. Turkey's Zero-Problems Foreign Policy. (Online), (http://foreignpolicy.com/2010/05/20/turkeys-zeroproblems-foreign-policy/).

Hill and Smith. 2011. International Relations and the European Union. New York: Oxford University press.

Hudson, M., Valerie, Vore, S., Christopher. 1995. Foreign Policy 
Analysis Yesterday,

Today, and Tomorrow. Mershon International Studies Review (online), Volume 39, Issue 2, October 1995, (http://www.jstor.org). A Guide to The United States' History of Recognition, Diplomatic, and Consular Relations, by Country, Since 1776: Turkey. (Online), (https://history.state.gov/countries/turkey). Turkish Foreign Policy During Ataturk's Era. (online), (http:// www.mfa.gov.tr/turkish-foreign-policy-during-ataturks-era.en.mfa) Jackson, J., Robert. 2013. Global Politics in the 21th Century. New York: Cambridge University Press.

Kapucu, Naim, Palabiyik, Hamit. 2008. Turkish Public Administration from Tradition to the

Modern Age. Ankara: International Strategic Research Organization (ISRO).

Modebadze, Valeri, Sayin, Mehmet, Fatih. 2015. Why Turkey Should Join the European

Union: Arguments In Favor of Turkish Membership. The Institute for Research and European Studies: Journal of Liberty and International Affairs (online), Vol. 1, No. 2. (http://e-jlia.com/papers/ v2_8.pdf.)

Müftüler-Baç, Meltem. (n.d.). Turkish Foreign Policy in Turbulent Times. (Online), (http:/Mww.E-ir.info/2015/01/25/turkish-foreign-policyin-turbulent-times/).

Neack, Laura. 2008. The New Foreign Policy Power Seeking in a Globalized Era. The U.S.A: Rowman \& Littlefield Publishers, Inc.

Sayari, Sabri. (n.d.). The United States and Turkey's Membership in The European Union. (Online), (http://dergiler.ankara.edu.tr/dergiler/44/ 674/8589.pdf)

Turan, Ilter. 2011. Turkish Foreign Policy: Interplay Between the Domestic and External. Carnegie Endowment for International Peace. (Online), (http://carnegieendowment.org/2011/09/21/ turkish-foreign-policy-interplay-between-domestic-and-external\#).

Zanotti, Jim. 2015. Turkey: Background and U.S. Relations. Congressional Research

Service (online). (www.crs.gov). 